\title{
ASUHAN KEPERAWATAN PASIEN PPOK MENGGUNAKAN POSISI CONDONG KE DEPAN DAN LATIHAN PURSED LIP BREATHING UNTUK MENINGKATKAN SATURASI OKSIGEN
}

\author{
Nursing Care for COPD Patients Using a Forward Leaning Position and Pursed Lip Breathing \\ Training to Improve Oxygen Saturation
}

Regita Putri Cahyani, Pujiarto*, Nandita Wana Putri

Sekolah Tinggi Ilmu Kesehatan Panca Bhakti

*Email korespondensi: pujiart_77@yahoo.com

\begin{abstract}
ABSTRAK
Pendahuluan: Penyakit paru obstruktif kronik (PPOK) adalah penyakit yang ditandai dengan hambatan aliran udara di saluran nafas (paru-paru) yang tidak sepenuhnya reversibel. Orang dengan PPOK akan mengalami kelemahan otot inspirasi dan disfungsi otot yang berkontribusi terhadap terjadinya sesak nafas. Tujuan penelitian ini adalah untuk mengetahui dan mengidentifikasi keefektifan posisi condong ke depan (CKD) dan latihan pernafasan pursed lip breathing (PLB) terhadap peningkatan saturasi oksigen pasien PPOK yang dirawat di wilayah kerja Puskesmas Gedong Air Bandar Lampung. Metode penelitian ini menggunakan metode eksperimen dengan rancangan penelitian terapan (Applied Research).Subyek penelitian yang diambil 2 orang yang sesuai dengan kriteria inklusi.Intervensi penelitian ini menggunakan pulse oxymeter, SOP latihan pursed lip breathing dan SOP latihan posisi condong kedepan. Penelitian ini menunjukkan bahwa setelah diberikan intervensi penerapan posisi condong ke depan dan latihan pursed lip breathing selama 3 hari berturut-turut pada responden pertama Tn.A terdapat peningkatan saturasi oksigen yaitu dari $95 \%$ menjadi $98 \%$ dan pada responden kedua Tn.K juga terjadi peningkatan saturasi oksigen yaitu dari $94 \%$ menjadi $98 \%$. Hasil yang diperoleh dari penelitian ini terdapat pengaruh terhadap peningkatan saturasi oksigen kedua responden setelah diberikan terapi posisi condong ke depan dan latihan pursed lip breathing. Saran: Dapat menerapkan intervensi posisi condong ke depan dan latihan pursed lip breathinguntuk meningkatkan saturasi oksigen pada pasien PPOK.
\end{abstract}

Kata kunci: Posisi condong kedepan; PPOK; Pursed lip breathing; Saturasi oksigen;

\begin{abstract}
Introduction: Chronic obstructive pulmonary disease (COPD) is a disease characterized by obstruction of airflow in the airways (lungs) that is not completely reversible. People with COPD will experience inspiratory muscle weakness and muscle dysfunction that can contribute to shortness of breath. The aim of this study was to determine and identify the effectiveness of forward leaning (CKD) and pursed lip breathing (PLB) breathing exercises to increase oxygen saturation of COPD patients being treated in Puskesmas Gedong Air Bandar Lampung. Research method uses experimental methods with applied research design (Applied Research). The research subjects were taken by 2 people who fit the inclusion criteria. The intervention of this study used a pulse oxymeter, pursed lip breathing exercise SOP and forward leaning training SOP. This study shows that after being given the intervention to apply forward leaning positions and pursed lip breathing exercises for 3 consecutive days in the first respondent Mr. A. there was an increase in oxygen saturation, from $95 \%$ to $98 \%$ and in the second respondent $\mathrm{Mr}$. K also increased. oxygen saturation ie from $94 \%$ to $98 \%$. The results obtained from this study showed an effect on the increase in oxygen saturation of the two respondents after being given forward leaning therapy and pursed lip breathing exercises. Suggestion: Can implement forward leaning and pursed lip breathing exercises to increase oxygen saturation in COPD patients
\end{abstract}

Keywords: COPD; Forward leaning position; Oxygen saturation; Pursed lip breathing;

https://doi.org/10.33860/mnj.vli2.277

(C) 2020 by the authors. Submitted for possible open access publication under the terms and conditions of the Creative Commons Attribution (CC BY SA) license (https://creativecommons.org/licenses/by-sa/4.0/). 


\section{PENDAHULUAN}

PPOK merupakan suatu istilah yang sering digunakan untuk sekelompok penyakit paru yang berlangsung lama dan ditandai oleh peningkatan resistensi terhadap aliran udara sebagai gambaran patofisiologi utamanya. ${ }^{1}$ PPOK dianggap sebagai penyakit yang berhubungan dengan interaksi genetik dengan lingkungan. Merokok, polusi udara, dan pemajanan di tempat kerja (terhadap batu bara, kapas, dan padi-padian) merupakan faktor-faktor- risiko penting yang menunjang terjadinya penyakit ini. ${ }^{2}$

Menurut World Health Organization (WHO, 2015), penyakit paru obstruktif kronik (PPOK) adalah penyakit yang ditandai dengan hambatan aliran udara di saluran nafas (paru-paru) yang tidak sepenuhnya reversibel. ${ }^{3}$ Laporan WHO Penyakit paru obstruktif kronik (PPOK) adalah penyakit yang dapat dicegah dan diobati, ditandai dengan keterbatasan aliran udara yang terus-menerus yang biasanya progresif dan berhubungan dengan respons inflamasi kronis pada saluran napas dan paru-paru terhadap partikel atau gas yang beracun. ${ }^{4}$

Prevalensi kejadian PPOK di dunia rata-rata berkisar 3-11\%. ${ }^{4}$.Pada tahun 2013, di Amerika Serikat PPOK adalah penyebab utama kematian ketiga, dan lebih dari 11 juta orang telah didiagnosis dengan PPOK. ${ }^{5}$ Menurut data penelitian dari Regional COPD Working Group yang dilakukan di 12 negara di Asia Pasifik rata-rata prevalensi PPOK sebesar 6,3\%, dengan yang terendah $3,5 \%$ di Hongkong dan Singapura, dan tertinggi di Vietnam sebanyak 6,7\%. Indonesia menunjukkan prevalensi sebanyak 5,6\% atau 4,8 juta kasus untuk PPOK derajat sedang sampai berat. $^{4}$

Hasil Riset Kesehatan Dasar (Riskesdas) pada tahun 2018 didapatkan prevalensi PPOK di Indonesia sebanyak 4,5\% dengan prevalensi terbanyak yaitu Provinsi Sulawesi Tengan sebanyak 5,5\%, NTT sebanyak 5,4\%, dan Lampung sebanyak 1,3\%. Angka-angka tersebut menunjukan semakin meningkatnya kematian akibat penyakit PPOK. ${ }^{6}$

Pasien PPOK mengalami kelemahan otot inspirasi dan disfungsi otot yang berkontribusi terhadap terjadinya sesak nafas. Salah satu dari latihan nafas yang efektif dalam membantu mengatasi sesak nafas adalah pursed lips breathing (PLB) yang merupakan salah satu teknik latihan pernafasan yang melibatkan pernafasan melalui perlawanan yang diciptakan dengan penyempitan bibir. Pernapasan pursed lips breathing dapat memperbaiki pertukaran gas yang dapat dilihat dengan membaiknya saturasi oksigen arteri. Pursed lips breathing juga memperbaiki pola nafas dan meningkatkan volume tidal.Selain itu, pursed lips breathing bertujuan memberikan manfaat subjektif pada penderita yaitu mengurangi sesak, rasa cemas dan tegang karena sesak. $^{7}$

Penelitian Tarigan dan Juliandi (2018) menunjukkan bahwa terdapat perbedaan rata-rata saturasi oksigen penderita PPOK sebelum dan sesudah dilakukan latihan nafas pursed lip breathing. Sebelum dilakukan latihan nafas dalam pursed lip breathing rerata saturasi oksigen responden adalah $96,72 \%$, setelah dilakukan pursed lip breathing saturasi oksigen naik sebesar 1,39 menjadi $98,11 \%$. Hal ini menunjukkan bahwa ada pengaruh latihan nafas dalam pursed lip breathing terhadap peningkatan saturasi oksigen penderita PPOK. ${ }^{7}$

Tindakan keperawatan lain yang dapat dilakukan untuk membantu meningkatkan kondisi pernafasan pasien PPOK adalah memposisikan pasien. Posisi condong ke depan meningkatkan tekanan intraabdominal dan menurunkan penekanan diafragma kebagian rongga abdomen selama inspirasi. ${ }^{8}$ Pada penelitian yang dilakukan oleh Isnainy \& Ayungtias (2019) posisi condong ke depan (CKD) dapat membantu meningkatkan kondisi pernafasan. ${ }^{9}$

Penelitian Hilma et al (2019) menunjukkan bahwa rata - rata nilai saturasi oksigen pada pasien PPOK sebelum dilakukan tripod position adalah $94,47 \%$ dan setelah dilakukan intervensi tripod position selama 3 hari berturut - turut selama 15 menit, rata - rata nilai saturasi oksigen adalah 94,76\%. Berdasarkan hasil penelitian ini juga, menunjukkan bahwa rata - rata nilai saturasi oksigen pada pasien PPOK sebelum dilakukan pursed lips breathing dengan full fowler adalah 94,00\% dan setelah dilakukan intervensi pursed lips breathing selama 3 hari berturut - turut selama 15 menit, rata - rata nilai saturasi oksigen adalah $95,23 \% .^{10}$ Berdasarkan fenomena tersebut penulis tertarik untuk melakukan asuhan keperawatan pada pasien PPOK menggunakan posisi condong ke depan dan latihan pursed lip breathing untuk meningkatkan saturasi oksigen di wilayah kerja Puskesmas Gedong Air Bandar Lampung. 


\section{METODE PENELITIAN}

Metode penelitian ini menggunakan metode eksperimen dengan rancangan penelitian terapan (Applied Research). Subyek penelitian yang diambil 2 orang yang sesuai dengan kriteria inklusi. Intervensi penelitian ini menggunakan Pulse Oxymeter, SOP Latihan Pursed Lip Breathing dan SOP Latihan Posisi Condong Kedepan.

\section{HASIL PENELITIAN}

Berdasarkan data karakteristik responden pada klien 1 yaitu Tn. A usia 68 tahun status perkawinan menikah, pekerjaan adalah Wiraswasta, beragama Islam, pendidikan terakhir SMA alamat rumah Jl.Sam Ratulangi terdiagnosa PPOK. Sementara pada klien 2 adalah Tn. K usia 70 tahun status menikah pekerjaan pensiunan beragama Islam alamat rumah Gunung Agung, dan terdiagnosa PPOK.

Sebelum dilakukan terapi, pasien 1 menggunakan obat hirup seretide diskus $50 / 250 \mathrm{mcg}$ pada tanggal 15 Juni 2020 pukul 07.30 WIB dan pasien 2 menggunakan obat hirup spiriva respimat inhaler $2.5 \mathrm{mcg}$ pada tanggal 15 Juni 2020 pukul 07.00 WIB. Pasien menggunakan jenis obat yang sama yaitu obat hirup untuk mengurangi rasa sesak nafas. Penerapan posisi condong ke depan dan latihan pursed lip breathing diberikan kepada kedua subyek dihari yang sama, jam berbeda, selama 3 hari berturut-turut. Pasien 1 yaitu Tn.A dilakukan penerapan hari pertama tanggal 15 Juni 2020 pukul 10.00 WIB dan pasien 2 yaitu Tn.K dilakukan penerapan hari pertama tanggal 15 Juni 2020 pukul 13.00 WIB. Sebelum dilakukan penerapan posisi condong ke depan dan latihan pursed lip breathing terlebih dahulu pasien dilakukan pengukuran saturasi oksigen kemudian mulai melakukan posisi condong ke depan dan latihan pursed lip breathing sesuai SOP. Penerapan posisi condong ke depan dan latihan pursed lip breathing dilakukan bersama-sama selama 15 menit dengan 3 kali istirahat, 5 menit untuk setiap kali istirahat. Pada saat dilakukan penerapan posisi condong ke depan dan latihan pursed lip breathing pasien sangat kooperatif dan melakukan terapi dengan baik
Tabel 1

Saturasi Oksigen Sebelum Dilakukan Penerapan Posisi Condong Ke Depan Dan Latihan Pursed Lip Breathing

\begin{tabular}{ccc}
\hline $\begin{array}{l}\text { Hari } \\
\text { penelitian }\end{array}$ & $\mathrm{SPO}_{2}$ Tn.A & $\mathrm{SPO}_{2} \mathrm{Tn} . \mathrm{K}$ \\
\hline 1 & $95 \%$ & $94 \%$ \\
\hline 2 & $96 \%$ & $95 \%$ \\
\hline 3 & $98 \%$ & $98 \%$ \\
\hline
\end{tabular}

Dari tabel diatas dijelaskan bahwa dilakukan pengukuran saturasi oksigen menggunakan pulse oxymeter. Pasien pertama Tn.K, pada hari pertama tanggal 15 Juni 2020 pukul 10.00 WIB sebelum dilakukan penerapan posisi condong ke depan dan latihan pursed lip breathing SPO2 Tn.A adalah 95\%, pada hari kedua tanggal 16 Juni 2020 di jam yang sama sebelum dilakukan penerapan didapatkan hasil SPO2 Tn.A adalah 96\%, dan pada hari ketiga tanggal 17 Juni 2020 di jam yang sama sebelum dilakukan penerapan didapatkan hasil SPO2 Tn.A adalah $98 \%$.

Pada pasien kedua yaitu Tn.K, pada hari pertama tanggal 15 Juni 2020 pukul 13.00 WIB sebelum dilakukan penerapan posisi condong ke depan dan latihan pursed lip breathing SPO2 Tn.K adalah 94\%, pada hari kedua tanggal 16 Juni 2020 di jam yang sama sebelum dilakukan penerapan SPO2 Tn.K adalah 95\%, dan pada hari ketiga tanggal 17 Juni 2020 di jam yang sama sebelum dilakukan penerapan SPO2 Tn.K adalah $98 \%$.

Tabel 2

Saturasi Oksigen Setelah Dilakukan Penerapan Posisi Condong Ke Depan Dan Latihan Pursed Lip Breathing

\begin{tabular}{ccc}
\hline $\begin{array}{c}\text { Hari } \\
\text { penelitian }\end{array}$ & $\mathrm{SPO}_{2} \mathrm{Tn} . \mathrm{A}$ & $\mathrm{SPO}_{2} \mathrm{Tn} . \mathrm{K}$ \\
\hline 1 & $96 \%$ & $95 \%$ \\
\hline 2 & $98 \%$ & $96 \%$ \\
\hline 3 & $98 \%$ & $98 \%$ \\
\hline
\end{tabular}

Setelah dilakukan penerapan posisi condong ke depan dan latihan pursed lip breathing saturasi pasien kembali diukur menggunakan pulse oxymeter, pada hari pertama tanggal 15 Juni 2020 pukul 10.30 WIB setelah dilakukan penerapan posisi condong ke depan dan latihan pursed lip breathing SPO2 Tn.A adalah 
96\%, pada hari kedua tanggal 16 Juni 2020 pukul 10.30 WIB setelah dilakukan penerapan SPO2 Tn.A adalah $98 \%$, dan pada hari ketiga tanggal 17 Juni 2020 pukul 10.30 WIB setelah dilakukan penerapan SPO2 Tn.A adalah $98 \%$.

Pada pasien kedua yaitu Tn.K, pada hari pertama tanggal 15 Juni 2020 pukul 13.30 WIB setelah dilakukan penerapan posisi condong ke depan dan latihan pursed lip breathing SPO2 Tn.K adalah 95\%, pada hari kedua tanggal 16 Juni 2020 pukul 13.30 WIB setelah dilakukan penerapan SPO2 Tn.K adalah $96 \%$, dan pada hari ketiga tanggal 17 Juni 2020 pukul 13.30 setelah dilakukan penerapan SPO2 Tn. K adalah $98 \%$.

Tabel 3

Saturasi Oksigen Sebelum dan Sesudah dilakukan Penerapan Posisi Condong Ke Depan dan Latihan Pursed Lip Breathing Selama 3 Hari Berturut-turut

\begin{tabular}{ccccc}
\hline Inisial & \multicolumn{2}{c}{ Saturasi Oksigen } & $\begin{array}{c}\text { Rata- } \\
\text { rata }\end{array}$ \\
\cline { 2 - 4 } & $\begin{array}{c}\text { Hari } \\
\text { ke-1 }\end{array}$ & $\begin{array}{c}\text { Hari } \\
\text { ke-2 }\end{array}$ & $\begin{array}{c}\text { Hari } \\
\text { Ke-3 }\end{array}$ & \\
\hline Tn.A & & & & \\
Sebelum & $95 \%$ & $96 \%$ & $98 \%$ & $96,33 \%$ \\
Sesudah & $96 \%$ & $98 \%$ & $98 \%$ & $97,33 \%$ \\
\hline Tn.K & & & & \\
Sebelum & $94 \%$ & $95 \%$ & $98 \%$ & $95,67 \%$ \\
Sesudah & $95 \%$ & $96 \%$ & $98 \%$ & $96,33 \%$ \\
\hline
\end{tabular}

Dari tabel di atas dapat dijelaskan perubahan sebelum dan sesudah dilakukan penerapan posisi condong ke depan dan latihan pursed lip breathing pada 2 responden sesuai dengan standar operasional prosedur selama 3 hari berturut-turut.

Pada responden 1 yaitu Tn. A terjadi peningkatan saturasi oksigen setelah dilakukan penerapan posisi condong ke depan dan latihan pursed lip breathing, pada hari pertama sebelum dilakukan penerapan saturasi oksigen responden adalah 95\%, setelah dilakukan penerapan saturasi oksigen responden mengalami peningkatan menjadi 96\%. Pada hari kedua sebelum dilakukan penerapan saturasi oksigen responden adalah 96\%, setelah dilakukan penerapan saturasi oksigen responden mengalami peningkatan menjadi 98\%.Pada hari ketiga sebelum dilakukan penerapan saturasi oksigen responden adalah $98 \%$, setelah dilakukan penerapan saturasi oksigen responden tetap $98 \%$.

Pada responden 2 yaitu Tn.K terjadi peningkatan saturasi oksigen setelah dilakukan penerapan posisi condong ke depan dan latihan pursed lip breathing, pada hari pertama sebelum dilakukan penerapan saturasi oksigen responden adalah 94\%, setelah dilakukan penerapan saturasi oksigen responden mengalami peningkatan menjadi 95\%. Pada hari kedua sebelum dilakukan penerapan saturasi oksigen responden adalah 95\%, setelah dilakukan penerapan saturasi oksigen responden mengalami peningkatan menjadi 96\%.Pada hari ketiga sebelum dilakukan penerapan saturasi oksigen responden adalah 98\%, setelah dilakukan penerapan saturasi oksigen responden tetap $98 \%$.

Berdasarkan data di atas kedua responden mengalami peningkatan saturasi oksigen setelah dilakukan penerapan posisi condong ke depan dan latihan pursed lip breathing. Sebelum dilakukan penerapan posisi condong ke depan dan latihan pursed lip breathing saturasi oksigen pada kedua responden berada direntang yang tidak normal.

Pada responden pertama yaitu Tn. A rata-rata saturasi oksigen sebelum dilakukan penerapan posisi condong ke depan dan latihan pursed lip breathing selama 3 hari berturut-turut adalah 96,33\% dan rata-rata saturasi oksigen Tn.A setelah dilakukan penerapan posisi condong ke depan dan latihan pursed lip breathing selama 3 hari berturut-turut adalah 97,33\%.

Pada responden kedua yaitu $\mathrm{Tn}$. K rata-rata saturasi oksigen sebelum dilakukan penerapan posisi condong ke depan dan latihan pursed lip breathing selama 3 hari berturut-turut adalah 95,67\% dan rata-rata saturasi oksigen Tn.K setelah dilakukan penerapan posisi condong ke depan dan latihan pursed lip breathing selama 3 hari berturut-turut adalah 96,33\%. 


\section{PEMBAHASAN}

\section{Karakteristik Responden}

Pada penelitian ini, kedua responden yaitu Tn.A dan Tn.K berjenis kelamin laki-laki.Secara teori, faktor jenis kelamin sebenarnya belum diketahui secara pasti kaitannya dengan PPOK.Jenis kelamin pada PPOK ini dikaitkan dengan konsumsi rokok, dimana lebih banyak ditemukan perokok pada laki-laki dibandingkan pada wanita. Data Riskesdas (2018) menunjukkan 62,9\% merupakan perokok laki-laki dan $4,8 \%$ perokok wanita.

Berdasarkan usia, kedua responden yaitu Tn.A dan Tn.K tergolong lansia berusia diatas 65 tahun. Menurut Astuti et al (2017) semakin bertambah umur seseorang maka akan terjadi degenerasi otot-otot pernafasan dan elastisitas jaringan menurun. Sehingga kekuatan otot-otot pernafasan dalam menghirup oksigen menjadi menurun.Kemudian karena faktor umur yang bertambah maka semakin banyak alveoli yang rusak dan daya tahan tubuh semakin rendah.

Berdasarkan data riwayat kesehatan dahulu, kedua responden memiliki riwayat sebagai perokok aktif, terpapar langsung dengan polusi, dan pemajanan debu ditempat kerja. Menurut WHO (2015) penyebab utama PPOK adalah tembakau (pengguna maupun perokok pasif) ${ }^{4}$ PPOK dianggap sebagai penyakit yang berhubungan dengan interaksi genetik dengan lingkungan. Merokok, polusi udara, dan pemajanan di tempat kerja (terhadap batu bara, kapas, dan padipadian) merupakan faktor-faktor- risiko penting yang menunjang terjadinya penyakit ini. ${ }^{2}$

Penerapan Posisi Condong Ke Depan dan Latihan Pursed Lip Breathing Untuk Meningkatkan Saturasi Oksigen Pada Pasien PPOK.

Hasil penerapan posisi condong ke depan dan latihan pursed lip breathing untuk meningkatkan saturasi oksigen pada pasien PPOK di wilayah kerja puskesmas gedong air bandar lampung adalah pada hari pertama tanggal 15 Juni 2020 saturasi oksigen Tn.A yaitu 96\%, pada hari kedua tanggal 16 Juni 2020 saturasi oksigen Tn.A mengalami peningkatan yaitu 98\%, dan pada hari ketiga tanggal 17 Juni 2020 saturasi oksigen Tn.A menjadi 98\%. Pada pasien kedua, pada hari pertama tanggal 15 Juni 2020 saturasi oksigen Tn.K adalah 95\%, pada hari kedua tanggal 16 Juni 2020 saturasi oksigen Tn.K mengalami peningkatan yaitu $96 \%$, dan pada hari ketiga tanggal 17 Juni 2020 menjadi 98\%.
Berdasarkan data di atas, rata-rata saturasi oksigen pada responden pertama Tn. A sebelum dilakukan penerapan posisi condong ke depan dan latihan pursed lip breathing selama 3 hari berturut-turut adalah $96,33 \%$ dan rata-rata saturasi oksigen setelah dilakukan penerapan posisi condong ke depan dan latihan pursed lip breathing selama 3 hari berturutturut adalah $97,33 \%$. Selisih peningkatan saturasi oksigen sebelum dan sesudah dilakukan penerapan pada Tn. A adalah 1\%. Pada responden kedua Tn. K sebelum dilakukan penerapan posisi condong ke depan dan latihan pursed lip breathing selama 3 hari berturut-turut adalah 95,67\% dan rata-rata saturasi oksigen setelah dilakukan penerapan posisi condong ke depan dan latihan pursed lip breathing adalah $96,33 \%$. Selisih peningkatan saturasi oksigen sebelum dan setelah dilakukan penerapan pada Tn.K adalah $0,66 \%$.

Berdasarkan hasil penelitian, penerapan posisi condong ke depan dan latihan pursed lip breathing efektif meningkatkan saturasi oksigen pada pasien dengan PPOK. Keadaan sesak nafas yang dibiarkan terus menerus tanpa disadari akan menurunkan saturasi oksigen yang selanjutnya dapat menyebabkan sianosis pada penderita PPOK. ${ }^{11}$ Hal ini sejalan dengan penelitian yang dilakukan oleh Kim et al (2012) bahwa posisi condong ke depan (CKD) dapat membantu meningkatkan kondisi pernafasan. ${ }^{12}$ Hasil penelitian Khasanah (2015) menyatakan posisi condong ke depan dapat mempermudah pasien dengan PPOK melakukan inspirasi. ${ }^{13}$

Hal ini juga sejalan dengan penelitian Tarigan dan Juliandi (2018) yang menyatakan bahwa pernapasan pursed lips breathing dapat memperbaiki pertukaran gas yang dapat dilihat dengan membaiknya saturasi oksigen arteri. Pursed lips breathing juga memperbaiki pola nafas.Selain itu, pursed lips breathing bertujuan memberikan manfaat subjektif pada penderita yaitu mengurangi sesak dan tegang karena sesak. $^{7}$

Dalam penelitian ini, penerapan posisi condong ke depan dan latihan pursed lip breathing dilakukan bersama-sama selama 3 hari berturut-turut dengan waktu 15 menit dan 3 kali istirahat, 5 menit untuk setiap kali istirahat. Hal ini sejalan dengan penelitian Khasanah (2015) dengan judul "Efektifitas Posisi Condong Ke Depan dan Pursed Lips Breathing (PLB) 
Terhadap Peningkatan Saturasi Oksigen Pasien Penyakit Paru Obstruktif Kronik" yang melakukan penelitian dengan 25 responden yang diberikan perlakuan posisi condong ke depan dan latihan pursed lip breathing secara bersama-sama selama 3 hari berturut-turut, dimana setiap kali dilakukan tindakan tersebut pasien diberi kesempatan untuk beristirahat setiap 5 menit sebanyak 3 kali. Hasil dari penelitian Khasanah (2015) adalah posisi condong ke depan dan latihan pursed lip breathing efektif meningkatkan saturasi oksigen pada pasien PPOK dengan pv=0,004 .

\section{SIMPULAN DAN SARAN}

Berdasarkan penelitian yang dilakukan dapat diambil kesimpulan bahwa terjadi perubahan yang signifikan antara sebelum dan setelah penerapan posisi condong ke depan dan latihan pursed lip breathing pada pasien PPOK untuk meningkatkan saturasi oksigen. Saran bagi peofesi keperawatan agar meningkatkan kemauan dalam menerapkan intervensi posisi condong ke depan dan latihan pursed lip breathing untuk meningkatkan saturasi oksigen pada pasien PPOK dan dapat meningkatkan kemampuan profesi keperawatan dalam melakukan pemberian intervensi, meningkatkan kemampuan komunikasi dan interaksi dengan klien.

\section{DAFTAR PUSTAKA}

1. Price SA, Wilson LM. Patofisiologi: Konsep Klinis Proses-Proses Penyakit. Jakarta: EGC; 2012.

2. Brunner, Suddart. Buku Ajar Keperawatan Medikal Bedah. Edisi Revi. Jakarta: EGC; 2015.

3. Maidartati. Pengaruh Fisioterapi Dada Terhadap Bersihan Jalan Nafas Pada Anak Usia 1-5 Tahun Yang Mengalami Gangguan Bersihan Jalan Nafas Di Puskesmas Moch. Ramdhan Bandung. Ilmu Keperawatan. 2014;2(1):47-56.

4. Global Initiative for Chronic Obstructive Lung Disease. Pocket guide to COPD diagnosis, management and prevention: a guide for health care professionals. Glob Initiat Chronic Obstr Lung Dis Inc [Internet]. 2018;3-14. Available from: http://goldcopd.org/wpcontent/uploads/2018/02/WMS-GOLD-2018Feb-Final-to-print-v2.pdf

5. American Lung Association. Trends in COPD ( Chronic Bronchitis and Emphysema ):
Morbidity and Mortality. America; 2013.

6. Kementrian Kesehatan Republik Indonesia. Laporan Hasil Riset Kesehatan Dasar [Internet]. 2018. Available from: https://www.litbang.kemkes.go.id/laporanriset-kesehatan-dasar-riskesdas/

7. Tarigan APS, Juliandi. Pernafasan Pursed Lip Breathing Meningkatkan Saturasi Oksigen Penderita Penyakit Paru Obstruktif Kronis (PPOK) Derajat II. J Online Keperawatan Indones. 2018;1(2).

8. Bhatt SP, Guleria R, Luqman-Arafath TK, Gupta AK, Mohan A, Nanda S, et al. Effect of tripod position on objective parameters of respiratory function in stable chronic obstructive pulmonary disease. Indian J Chest Dis Allied Sci [Internet]. 2009;51(2):83-5. Available from: http://www.ncbi.nlm.nih.gov/pubmed/194454 43

9. Isnainy UCAS, Sekardhyta Ayuning Tias. Pengaruh posisi condong kedepan dan terapi pursed lips breathing terhadap derajat sesak napas penderita Penyakit Paru Obstruktif Kronik ( PPOK ). Holistik J Kesehat. 2019;13(4):389-95.

10. Wahidati H, Dwiningsih SU, Putrono. The Effectiveness of Tripod Position And Pursed Lips Breathing to Enhance Oxygen Saturation in Patients With. Jendela Nurs J. 2019;3(2):6876.

11. Somantri I. Asuhan Keperawatan pada Klien dengan Gangguan Sistem Pernapasan. 2nd ed. Jakarta: Salemba Medika; 2009.

12. Kim K, Byun M, Lee W, Cynn H, Kwon O, Yi C. Effects of breathing maneuver and sitting posture on muscle activity in inspiratory accessory muscles in patients with chronic obstructive pulmonary disease. Multidiscip Respir Med [Internet]. 2012 Jun 20;7(1):9. Available from: ???

13. Khasanah S, Maryoto M. Efektifitas Posisi Condong Ke Depan (CKD) Dan Pursed Lips Breathing (PLB) Terhadap Peningkatan Saturasi Oksigen Pasien Penyakit Paru Obstruktif Kronik ( PPOK ). J RESPIROLOGI Indones. 2015;7(1). 